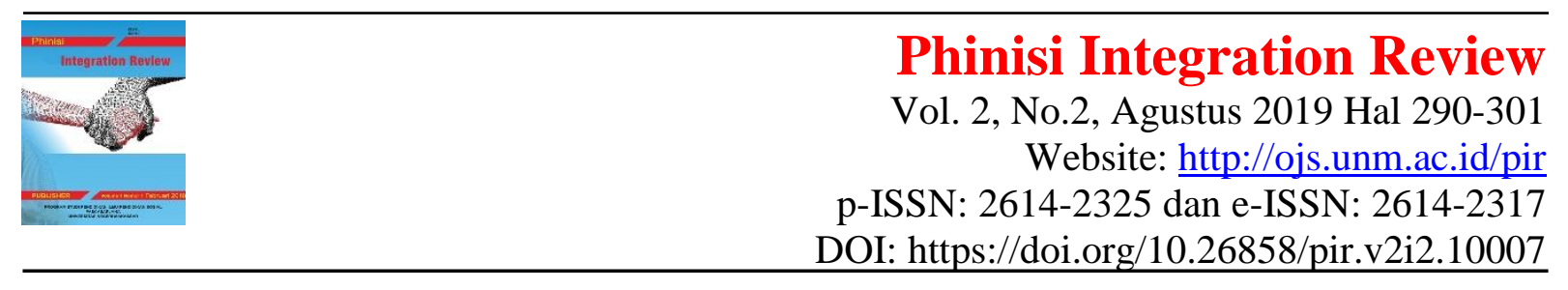

\title{
Remaja Putus Sekolah Akibat Hamil Pranikah
}

\author{
Mirna \\ Pendidikan Sosiologi, Pascasarjana Universitas Negeri Makassar \\ Email: mirna_28@yahoo.com
}

\begin{abstract}
Abstrak. Penelitian ini bertujuan untuk mengetahui: (i) penyebab remaja putus sekolah kasus hamil pranikah. (ii) dampak putus sekolah pada kasus hamil pranikah bagi pelaku dan keluarga. (iii) solusi dalam mengatasi putus sekolah pada kasus hamil pranikah. Jenis penelitian yang digunakan dalam penelitian ini adalah deskriptif kualitatif. Adapun teknik pengumpulan data yaitu dengan melakukan observasi, wawancara dan dokumentasi. Sedangkan penentuan informan menggunakan teknik purposive sampling, dalam hal ini peneliti memilih informan yaitu remaja di Kecamatan Ponrang Selatan yang mengalami putus sekolah kasus hamil pranikah, orang tua remaja yang mengalami hamil di luar nikah, dan pemerintah setempat yang masyaraktnya mengalami hamil pranikah. Dari hasil penelitian ditemukan bahwa (i) faktor yang menyebabkan remaja putus sekolah kasus hamil pranikah dikarenakan faktor keluarga, pergaulan bebas, perkembangan teknologi informasi dan komunikasi, tersedianya tempat wisata, dan kurangnya pendidikan agama yang dimiliki oleh remaja. (ii) dampak yang dirasakan oleh pelaku dan keluarga antara lain: dampak pendidikan, dampak sosial, dampak psikologis, dan dampak ekonomi. (iii) solusi mengatasi remaja putus sekolah kasus hamil pranikah dapat dilakukan melalui keluarga, lingkungan sekolah dan pendidikan agama.
\end{abstract}

Kata kunci : putus sekolah, hamil pranikah.

\begin{abstract}
The study aims at examining (i) the causes of drop out of school teenagers due to premarital pregnancy case, (ii) the impacts of drop out of school teenagers due to premarital pregnancy case for the actors and families, and (iii) the solution in overcoming drop out of school teenagers due to premarital pregnancy case.The type of this study was descriptive qualititave. Data were collected by conducting observation, interview, and documentation. The informants of the study were obtained by employing purposive sampling technique, in this case the researcher chose teenager informants in South Ponrang subdistrict who experienced drop out of school due to premarital pregnancy case, the parents, and local government. The results of the study reveal that (i) the factors which caused of drop out of school teenagers due to premarital pregnancy case are due to the family actor, promiscuity, development of information technology and communication, availability of tourist attraction, and lack of religious education of the teenagers, (ii) the impact felt by the actors and families among others are unclear future, disharmonic relation of the families, difficulty in social activities, and economic difficulties, and (iii) the solutions to overcome drop out if school teenagers due to premarital pregnancy case can be through family, school environment, and religious education,
\end{abstract}

Keywords: drop out of school, premarital pregnancy 


\section{PENDAHULUAN}

Pembangunan nasional sangat membutuhkan sumber daya manusia berkualitas. Untuk menciptakan manusia yang berkualitas harus dibekali dengan pendidikan. Melalui pendidikan, seseorang akan dapat mengembangkan potensi yang diperlukan dalam usaha menyesuaikan dan mengikuti perkembangan ilmu pengetahuan dan teknologi dari waktu ke waktu yang semakin berkembang pesat, serta untuk membebaskan manusia dari keterbelakangan, kebodohan, dan kemiskinan.

Pendidikan bagi kehidupan manusia merupakan kebutuhan mutlak yang harus dipenuhi sepanjang hayat. Karena proses pendidikan adalah suatu kegiatan secara bertahap berdasarkan perencanaan yang matang untuk mencapai tujuan atau cita-cita. Tanpa pendidikan mustahil suatu kelompok manusia dapat hidup berkembang sejalan dengan aspirasi (cita-cita) untuk maju, sejahtera menurut konsep pandangan mereka.

Namun cita-cita demikian tak mungkin dicapai jika manusia itu sendiri tidak berusaha keras meningkatkan kemampuannya seoptimal mungkin melalui proses pendidikan. Jika suatu bangsa ingin maju, maka kualitas sumber daya manusia harus ditingkatkan. Untuk itu, semua anak usia sekolah harus mengenyam pendidikan. Namun itu tidak sesuai dengan keadaan di Indonesia saat ini dimana masih banyak anak usia sekolah yang tidak dapat melanjutkan pendidikannya.

Remaja pada usia sekolah 12-19 tahun sangat rentan dengan berbagai perilaku yang mengarah kepada penyimpangan, misalnya kenakalan remaja, narkoba, kriminalitas dan pergaulan bebas dijadikan tempat pelarian untuk menunjukkan pencarian jati diri bagi mereka. Pada umumnya mereka memiliki kondisi emosional yang masih labil. Selalu mencari perhatian dari orang tua, teman, keluarga dan lingkungan masyarakatnya. Mereka mudah latah sehingga dengan mudah mengikuti pengaruh dari luar melalui teknologi dan informasi seperti tontonan di televisi dan internet yang sudah menjelajah hingga ke pelosok desa.

Perilaku melakukan hubungan seksual di luar nikah menjadi salah satu faktor penyebab terjadinya hamil pranikah pada remaja di Kecamatan Ponrang Selatan. Selain melakukan hubungan seksual di luar nikah, gagalnya pendidikan dalam keluarga, seperti orang tua yang terlalu sibuk bekerja sehingga mengabaikan tanggung jawabnya kepada anakanaknya untuk membimbing dan mengarahkan anak-anaknya juga menadi penyebab terjadinya putus sekolah kasus hamil pranikah. Putus sekolah kasus hamil pranikah juga disebabkan oleh pondasi pendidikan agama dalam keluarga yang minim, penanaman tentang norma-norma agama sejak usia dini tidak tersosialisasilan dengan baik. Tersedianya tempat wisata dan faktor lingkungan pergaulan bebas juga menjadi penyebab terjadinya hamil pranikah pada remaja di Kecamatan Ponrang Selatan.

Kasus hamil pranikah di Kecamatan Ponrang Selatan yang terjadi adalah pasangan pacaran. Dimulai dari pacaran inilah kemudian mengarah kepada perilaku seks bebas. Wilayah Kecamatan Ponrang Selatan yang didominasi kebun dan daerah yang sepi menjadi tempat yang dimanfaatkan pasangan remaja untuk berpacaran bahkan melakukan hubungan seks. Di sekitar wilayah ini terdapat penginapan murah yang kerap dijadikan tempat bagi pasangan remaja untuk melakukan hubungan seks.

Kasus hamil pranikah pada akhirnya akan berdampak pada perkawinan usia dini yang mengharuskan remaja untuk putus sekolah, karena keduanya dikawinkan secara terpaksa untuk mengurangi dan menutupi rasa malu yang ditanggung oleh keluarga.

Perkawinan karena hamil pranikah di Kecamatan Ponrang Selatan ini bahkan dianggap sangat memalukan, karena banyak terjadi gadis-gadis yang terpaksa dinikahkan karena kehamilannya yang sudah tak bisa ditutupi lagi. Beberapa contoh kasus misalnya gadis usia remaja yang menikah setelah usia kandungannya sudah 5-7 bulan karena kedua orang tuanya baru mengetahui kehamilan anaknya.

$\begin{array}{ccc} & \text { Atas dasar itulah yang membuat peneliti } \\ \text { merasa tertarik untuk mengungkap }\end{array}$ permasalahan yang terjadi mengenai "Remaja Putus Sekolah Akibat Hamil Pranikah" (Studi Kasus di Kecamatan Ponrang Selatan Kabupaten Luwu). Di sini penulis berusaha meneliti mengenai faktor-faktor apa saja yang menyebabkan banyak remaja putus sekolah kasus hamil pranikah, khususnya pada remaja usia 12-19 tahun atau sedang menempuh pendidikan SMP-SMU di Kecamatan Ponrang Selatan, dampak yang ditimbulkan bagi pelaku dan juga keluarga, serta solusi untuk mencegah permasalahan remaja putus sekolah kasus hamil pranikah. 


\section{TINJAUAN PUSTAKA}

\section{A. Remaja}

Masa remaja adalah masa yang menujukkan masa peralihan dari masa kanakkanak menuju ke masa selanjutnya yaitu masa dewasa. Pada masa remaja ini terjadi perkembangan-perkembangan seperti perkembangan fisik, psikologis, sosial, dan secara moral. Menurut Hall (Mussen, 1994:478), masa remaja merupakan masa topan badai, dimana pada masa tersebut timbul gejolak dalam diri akibat pertentanan nilai-nilai akibat kebudayaan yang makin modern. Batasan usia untuk remaja (adolescene) menurut Hall antara usia 12-25 tahun. Menurut Monks, remaja adalah usia peralihan antara masa remaja dan masa dewasa. Fase masa remaja secara globa berlangsung antara usia 12-21 tahun, dengan pembagian 12-15 tahun: masa remaja awal, 1518 tahun: masa remaja pertengahan, 18-21: masa remaja akhir (Monks, 2001:262).

Batasan usia menurut WHO adalah 1020 tahun, hal ini didasarkan atas kesehatan remaja yang mana kehamilan pada usia-usia tersebut memang mempunyai risiko yang lebih tinggi daripada kehamilan dalam usia -usia di atasnya (Sarwono 2002:9). Selanjutnya yang dimaksud dengan remaja adalah individu yang sedang mengalami masa peralihan dari masa kanak-kanak ke masa dewasa yang dalam rentangannya terjadi perubahan-perubahan dan perkembangan pada aspek fisik, psikologis, kognisi, dan sosialnya. Sedangkan, rentang usia pada masa remaja tersebut adalah antara 12-21 tahun.

\section{B. Putus Sekolah}

\section{Pengertian putus sekolah}

Putus sekolah atau drop out adalah mereka yang terpaksa berhenti sekolah sebelum waktunya (Martono HS dan Saidiharjo, 2002: 74). Seseorang dikatakan putus sekolah apabila seseorang tidak dapat menyelesaikan program suatu sekolah secara utuh yang berlaku sebagai suatu system (Bagong Suyanto, 2010). Pendapat lain menyatakan bahwa putus sekolah adalah meninggalkan sekolah sebelum menyelesaikan keseluruhan masa belajar yang telah ditetapkan oleh sekolah yang bersangkutan (Mudyaharjo, 2001: 498).

\section{Faktor penyebab anak putus sekolah}

Faktor penyebab anak putus sekolah terdiri dari beberapa unsur seperti kondisi sosial ekonomi yang kurang baik, keadaan sarana dan prasarana yang kurang mendukung, bahkan motivasi anak untuk bersekolah yang rendah. Selain faktor-faktor itu juga, faktor lingkungan tempat tinggal anak dan lingkungan bermain sangat berpengaruh terhadap keberlangsungan pendidikan anak.

\section{Hamil Pranikah}

\section{Pengertian Hamil Pranikah}

Hamil yaitu suatu proses pertemuan antara sel telur dan sperma sehingga menjadi embrio yang terjadi kepada wanita pada masa subur dengan salah satu ciri yaitu terlambatnya siklus haid. Hamil pranikah yaitu suatu proses kehamilan yang terjadi sebelum adanya sebuah pernikahan sehingga anak tidak memiliki status kewarganegaraan yang syah (Al Husaini : 2008 )

Hamil pranikah terjadi karena beberapa sebab antara lain disebabkan oleh pergaulan bebas, pemerkosaan, pola asuh orang tua, pergaulan, kehidupan ekonomi keluarga, lingkungan, dan lain sebagainya.

Seorang remaja yang tidak mampu mengendalikan diri, sehingga terlibat dalam kehidupan seksual secara bebas (di luar aturan norma sosial), misalnya seks pranikah, kumpul kebo (sommonleven), prostitusi, akan berakibat negatif seperti STD's (seksually transmitted diseases), kehamilan (pregnancy) drop-out dari sekolah. Biasanya merekalah yang memiliki sifat ketidakkonsistenan (inconsistency) antara pengetahuan, sikap, dan perilakunya. Misalnya, walaupun seesorang mempunyai pengetahuan dan sikap bahwa seksual-pranikah itu tidak baik, namun karena situasi dan kesempatan itu memungkinkan, serta ditunjang oleh niat untuk melakukan hubungan seks pranikah, maka individu ternyata tetap saja melakukan hal itu. Akibatnya perilakunya tidak konsisten dengan pengetahuan dan sikapnya (Dariyo, 2004: 88).

\section{Faktor penyebab hamil pranikah}

Selain itu menurut Sarwono (2001) menyatakan bahwa faktor yang mempengaruhi hamil di luar nikah adalah sebagai berikut:

1) Meningkatnya Libido seksualitas, hal ini bisa terjadi apabila seseorang memperoleh rangsangan dari luar yang ditangkap oleh indra, berupa video porno, gambar porno, adanya sentuhan dari lawan jenis, atau dipicu oleh faktor lain seperti cerita dewasa dan lain-lain.

2) Penundaan usia perkawinan. Penundaan usia perkawinan ini bisa saja menyebabkan seseorang menjadi lepas kontrol, karena 
hasrat dan kebutuhan akan seks yang sudah mencapai waktunya namun belum memperoleh penyaluran yang tepat, sehingga memicu adanya perilaku seks

3) Faktor lingkungan yang sangat besar pengaruhnya terhadap kejahatan seks remaja. Lingkungan modern telah menggiring remaja menuju eksperimen seks yang lepas kendali.

4) Pergaulan bebas. Pergaulan bebas bisa dimaknai sebagai pergaulan remaja yang tanpa batas. Mereka boleh melakukan apa saja tanpa ikatan aturan. Pergaulan bebas tak lepas dari peran dunia modern dengan tekhnologi informasinya yang merubah pandangan remaja terhadap seks. Padahal konsekuensi penyimpangan seks akan berakibat fatal bagi masa depannya. Kemajuan teknologi dan derasnya arus informasi menungkinkan dampak globalisasi terhadap individu terwujud kehidupan remaja di zaman sekarang juga telah diliputi suasana keterbukaan informasi mengenai seksualitas. Hingga terjadi krisis kemanusiaan menyeluruh sebagai akibat kekeliruan dalam sistem pengolahan hubungan antar manusia dan sistem pengolahan lingkungan yang salah (Jalaluddin : 2007).

\section{Dampak Hamil Pranikah}

Para ahli dari berbagai bidang pendidikan, sosiologi, ekonomi, kedokteran, hukum, menyimpulkan ada lima masalah konsekuensi logis dari kehamilan yang harus ditanggung oleh remaja (Dariyo, 2004: 94)., yaitu:

a. Konsekuensi terhadap pendidikan: putus sekolah (DO). Remaja wanita yang hamil, umumnya tidak memperoleh penerimaan sosial dari lembaga pendidikannya, sehingga ia harus dikeluarkan dari sekolahnya. Demikian pula, remaja laki-laki yang menjadi pelaku utama penyebab kehamilan itu, mau tidak mau juga akan mengalami nasib yang sama, yaitu drop-out dari sekolahnya.

b. Konsekuensi sosiologis: sangsi sosial. Orang tua yang anaknya hamil, akan menanggung rasa malu. Maka untuk menyelesaikan masalah ini, jalan terbaik ialah segera menikahkan anaknya yang hamil dengan remaja laki-laki (pelaku utama) yang menghamilinya. Demikian pula, masyarakat akan mencemooh, mengisolasi atau mengusir terhadap orangorang yang melanggar norma masyarakat.

c. Konsekuensi penyesuaian dalam kehidupan keluarga sebagai orang yang telah menikah, tentu remaja harus dapat menyesuaikan diri dalam keluarganya yang baru. Ketidakmampuan dalam menyesuaikan diri, sehingga sering terjadi konflik-konflik, pertengkaran, percek-cokan, maka akan dapat berakhir dengan perceraian. Dengan demikian, ia akan berstatus sebagai janda muda maupun duda muda.

d. Konsekuensi ekonomis: pemenuhan kebutuhan ekonomis keluarga. Menurut Kaplan (1997) dari segi sosial-ekonomi biasanya perempuan yang mengalami kehamilan di luar nikah masih tergolong dalam masa remaja sehingga dalam kehidupannya masih sangat tergantung dari orang tua atau pihak lain, biasanya belum memiliki penghasilan sendiri karena masih sekolah atau kuliah. Orang tua remaja maupun orang tua pasangan dianggap menjadi sumber bantuan terbesar untuk memenuhi kebutuhan remaja. Dukungan ekonomi yang orang tua berikan bukan hanya untuk remaja tetapi juga untuk anak maupun pasangan remaja (Khisbiyah, Murdijana \& Wijayanto, 1996).

e. Konsekuensi hukum. Karena telah hamil, maka untuk memperkuat rasa tanggung jawab, maka sebaiknya remaja melakukan pernikahan secara resmi yang diakui oleh pemerintah melalui kantor catatan sipil atau kantor urusan agama. Dengan menikah resmi, mereka akan terhindar dari sangsi sosial, sebab mereka menjadi suami-isteri yang sah. Sehingga kalau mereka mempunyai anak, maka anak tersebut sudah sah secara hukum yang tertuang dalam hukum perkawinan

\section{Landasan Teori}

Adapun teori yang digunakan peneliti sebagai landasan berpikir untuk membedah permasalahan yang terjadi pada masyarakat di Kecamatan Ponrang Selatan terkait dengan remaja putus sekolah akibat hamil pranikah adalah teori tindakan sosial oleh Max Weber.

Tindakan sosial menurut Max Weber adalah suatu tindakan individu sepanjang tindakan itu mempunyai makna atau arti subjektif bagi dirinya dan diarahkan kepada tindakan orang lain (Weber dalam Ritzer 1985). Suatu tindakan individu yang diarahkan kepada benda mati tidak masuk dalam kategori tindakan sosial. Suatu tindakan akan dikatakan sebagai tindakan social ketika 
tindakan tersebut benar-benar diarahkan kepada orang lain (individu lainnya). Meski tak jarang tindakan sosial dapat berupa tindakan yang bersifat membatin atau bersifat subjektif yang mungkin terjadi karena pengaruh positif dari situasi tertentu. Bahkan terkadang tindakan dapat berulang kembali dengan sengaja sebagai akibat dari pengaruh situasi yang serupa atau berupa persetujuan secara pasif dalam situasi tertentu (Weber dalam Turner 2000).

Weber membedakan tindakan sosial manusia ke dalam empat tipe yaitu:

1. Tindakan rasionalitas instrumental (Zwerk Rational)

Tindakan ini merupakan suatu tindakan sosial yang dilakukan seseorang didasarkan atas pertimbangan dan pilihan sadar yang berhubungan dengan tujuan tindakan itu dan ketersediaan alat yang dipergunakan untuk mencapainya. Contohnya : Seorang siswa yang sering terlambat dikarenakan tidak memiliki alat transportasi, akhirnya ia membeli sepeda motor agar ia datang kesekolah lebih awal dan tidak terlambat. Tindakan ini telah dipertimbangkan dengan matang agar ia mencapai tujuan tertentu. Dengan perkataan lain menilai dan menentukan tujuan itu dan bisa saja tindakan itu dijadikan sebagai cara untuk mencapai tujuan lain.

2. Tindakan rasional nilai (Werk Rational)

Sedangkan tindakan rasional nilai memiliki sifat bahwa alat-alat yang ada hanya merupakan pertimbangan dan perhitungan yang sadar, sementara tujuan-tujuannya sudah ada di dalam hubungannya dengan nilai-nilai individu yang bersifat absolut. Contoh : perilaku beribadah atau seseorang mendahulukan orang yang lebih tua ketika antri sembako. Artinya, tindakan sosial ini telah dipertimbangkan terlebih dahulu karena mendahulukan nilai-nilai sosial maupun nilai agama yang ia miliki.

$$
\begin{aligned}
& \text { 3. Tindakan afektif/Tindakan yang } \\
& \text { dipengaruhi emosi (Affectual Action) }
\end{aligned}
$$

Tipe tindakan sosial ini lebih didominasi perasaan atau emosi tanpa refleksi intelektual atau perencanaan sadar. Tindakan afektif sifatnya spontan, tidak rasional, dan merupakan ekspresi emosional dari individu. Contohnya: hubungan kasih sayang antara dua remaja yang sedang jatuh cinta atau sedang dimabuk asmara.Tindakan ini biasanya terjadi atas rangsangan dari luar yang bersifat otomatis sehingga bias berarti
4. Tindakan tradisional/Tindakan karena kebiasaan (Traditional Action)

Dalam tindakan jenis ini, seseorang memperlihatkan perilaku tertentu karena kebiasaan yang diperoleh dari nenek moyang, tanpa refleksi yang sadar atau perencanaan. Tindakan pulang kampong disaat lebaran atau Idul Fitri.

Berdasarkan teori tindakan yang dikemukakan Weber pada penjelasan di atas, maka teori yang sesuai dengan penelitian ini yaitu teori tindakan afektif. Hubungan seks yang dilakukan oleh remaja pranikah pada umumnya didasari oleh dorongan perasaan semata tanpa kesadaran penuh dalam memikirkan dampak yang akan terjadi setelahnya.

\section{METODE PENELITIAN}

Penelitian yang peneliti lakukan ini menggunakan pendekatan kualitatif. Taylor dan Bogdan (1984:5) dalam Bagong \& Sutinah (2005: 166) penelitian kualitatif merupakan penelitian yang menghasilkan data deskriptif mengenai kata-kata lisan maupun tertulis, dan tingkah laku yang dapat diamati dari orangorang yang diteliti. Dalam penelitian ini penulis menggambarkan keadaan-keadaan atau status fenomena yang terjadi yang dapat diamati dengan kata-kata tertulis maupun lisan dari orang-orang yang menjadi subjek penelitian. Secara prakteknya penulis sekaligus menggali informasi dari subjek penelitian kemudian hasil penelitian diungkapkan dengan kalimat

Sedangkan dasar penelitian yang digunakan adalah studi kasus yang bertujuan mempelajari secara mendalam mengenai keadaan kehidupan sekarang dengan latar belakangnya dalam interaksinya dengan lingkungan dari suatu unit sosial seperti individu, kelembagaan, komunitas ataupun masyarakat (Soetriono, 2007:164)

Penelitian ini akan dilakukan di Ponrang Selatan. Ponrang Selatan adalah sebuah kecamatan di Kabupaten luwu. Penelitian ini dilakukan di Kecamatan Ponrang Selatan dengan alasan dari hasil observasi awal melihat banyaknya terjadi kasus remaja putus sekolah akibat hamil pranikah

Dalam penelitian ini, penulis akan menggunakan beberapa metode dalam mengumpulkan data, diantaranya observasi, wawancara, dan dokumentasi yang mendukung demi kelancaran penelitian ini.

\section{Observasi}


Observasi diartikan sebagai pengamatan dan pencatatan secara sistematik terhadap suatu gejala yang tampak pada objek penelitian. Objek observasi dalam penelitian kualitatif terdapat tiga komponen, yakni place (tempat), actor (pelaku), dan activities (aktivitas) (Sugiyono, 2010: 314). Observasi adalah suatu tehnik pengumpulan data dimana peneliti mengadakan pengamatan secara langsung. Observasi sebagai metode ilmiah biasa diartikan sebagai pengamatan dan pencatatan secara sistematis terhadap fenomena-fenomena yang diselidiki, baik secara langsung maupun tidak langsung.

Black dan Champion mengelompokkan observasi dalam dua kelompok besar yaitu observasi non partisipan dan observasi partisipan. Observasi yang sesuai dengan penelitian adalah observasi non partisipan dimana peneliti tidak banyak dituntut peranan tingkah laku atau keterlibatannya terhadap kegiatan atau fenomena dari subjek yang diteliti. Perhatian peneliti hanya terfokus pada bagaimana mengamati, merekam, memotret, mempelajari, dan mencatat tingkah laku atau fenomena yang diteliti (Suprayogo, 2003: 167).

Pedoman observasi pengumpulan data dapat dikumpulkan sebagai berikut: Kondisi kehidupan remaja putus sekolah kasus hamil pranikah dan setelah menikah, baik aspek pendidikan, ekonomi, dan sosial. Dalam hal ini, peneliti mengobservasi pendidikan, ekonomi, dan sosial pada remaja, karena sesuai dengan data yang peneliti butuhkan dari remaja tersebut untuk menjawab rumusan masalah dalam penelitian ini, dengan cara observasi langsung terhadap responden dan lingkungan dimana responden berada.

\section{Metode Wawancara}

Teknik pengumpulan data selanjutnya ialah wawancara. Wawancara adalah cara untuk mendapatkan informasi dengan cara bertanya langsung kepada informan. Karena wawancara inilah salah satu bagian yang terpenting dari setiap penelitian. Oleh karena itu, melalui wawancara maka informasi yang diperoleh dapat dipastikan sesuai dengan kenyataan atau fakta terhadap suatu gejala yang sedang diamati, berbagai pihak yang peneliti minta keterangannya dalam penelitian antara lain: pihak putus sekolah, keluarga, kepala sekolah atau guru, pemerintah setempat, serta masyarakat pada umumnya yang mengetahui tentang putus sekolah dalam kasus hamil pranikah.
Dalam penelitian ini teknik wawancara yang peneliti gunakan adalah teknik wawancara semistruktur (semistructure interview), dimana dalam melakukan wawancara lebih bebas dan lebih terbuka dalam menentukan permasalahan. Dengan menggunakan jenis wawancara semistruktur Esterbeg dalam Sugiyono (2016:33) menyatakan jenis wawancara ini sudah terrmasuk dalam kategori in dept interview, dimana dalam pelakanaanya lebih bebas dibanding dengan wawancara sruktur. Tujuan dari wawancara seperti ini ialah untuk menemukan permasalahan secara lebih terbuka, dimana pihak yang diajak wawancara dimintai pendapat dan ide-idenya.

\section{Dokumentasi}

(Sugiyono, 2014) Menjelaskan bahwa dokumentasi adalah catatan peristiwa yang sudah berlalu.Pengambilan dokumentasi yang dilakukan peneliti disini yakni dilakukan dengan pengambilan gambar atau foto dan pengambilan rekaman video untuk memperkuat data-data yang telah dikumpulkan. Pengambilan foto atau video dapat dilakukan peneliti itu sendiri atau bantuan orang lain agar terlihat peran serta dalam penelitian.

Dalam penelitian ini menggunakan analisis data kualitatif deskriptif merupakan penggambaran keadaan atau fenomena yang diperoleh kemudian menganalisisnya dengan bentuk kata untuk diperoleh suatu kesimpulan.

Proses analisis data dimulai dengan menelaah seluruh data yang tersedia dari berbagai sumber, yaitu dari wawancara, pengamatan, dokumen resmi, dokumen pribadi, foto, video yang kemudian diadakan reduksi data. Dalam penelitian ini proses analisis data diawali dari mengumpulkan data-data yang diperoleh dari observasi, wawancara, maupun dokumentasi. Adapun tahapan analisis data yang akan digunakan dalam penelitian ini yakni (1) reduksi data, (2) Penyajian data (Display data), (3) Conclusion drawing/verification.

Pemeriksaan keabsahan data sangat diperlukan dalam penelitian kualitatif demi kesasihan dan keandalan serta tingkat kepercayaan data yang telah terkumpul. Pengembangan validitas yang digunakan oleh peneliti adalah teknik triangulasi. Triangulasi dalam menguji kredibilitas sebagai pengecekan data dari berbagai sumber, cara, dan waktu. Sugiyono (2008 : 274) triangulasi dibagi menjadi tiga, antara lain sebagai berikut : 
1. Triangulasi sumber, menguji kredibilitas data dilakukan dengan cara mengecek data yang telah diperoleh melalui beberapa sumber

2. Triangulasi teknik, menguji kredibilitas data dilakukan dengan cara mengecek data kepada sumber yang sama dengan teknik yang berbeda.

3. Triangulasi waktu, waktu juga sering mempengaruhi kredibilitas data. Pengambilan data harus disesuaikan dengan kondisi narasumber.

Dalam penelitian ini peneliti menggunakan triangulasi sumber, dengan arti peneliti membandingkan informasi yang diperoleh dari satu sumber dengan sumber lain.

\section{HASIL DAN PEMBAHASAN}

\section{A. Faktor-faktor yang Menyebabkan Terjadinya Putus Sekolah Kasus Hamil Pranikah}

\section{Keluarga}

Kegagalan fungsi keluarga dalam memainkan perannya sebagai tempat awal kehidupan remaja merupakan faktor marak terjadinya perilaku seks pranikah di kalangan remaja. Ini sesuai dengan apa yang di katakan oleh (Sudarsono : 2004) mengatakan bahwa seks bebas atau seks pranikah berawal dari kenakalan remaja. Sedangkan, kenakalan remaja sendiri berawal dari gagalnya pendidikan dalam keluarga seperti broken home, perceraian, ayah yang tidak diketahui kemana.

Remaja yang melakukan penyimpangan, kebanyakan berasal dari lingkungan keluarga yang kurang memperoleh perhatian dan kasih sayang dari orang tua, bisa jadi kedua orang tuanya sibuk bekerja, kedua orang tua sering cekcok, pisah ranjang, dan perceraian (divorce of parents) (Dariyo, 2004: 109). Tetapi yang ditemukan dilapangan dari beberapa informan di Kecamatan Ponrang Selatan, faktor yang menyebabkan remaja mengalami putus sekolah kasus hamil pranikah yaitu karena kurang memperoleh perhatian dan kasih sayang dari orang tua karena sibuk bekerja. Kesibukan bekerja ini pada akhirnya membuat orang tua sering lupa untuk berinteraksi dengan anakanaknya dan membuat komunikasi dengan anak sangat kurang. Sehingga remaja mudah terjerumus ke dalam pergaulan bebas yang menyebabkan remaja hamil pranikah.

\section{Pergaulan Bebas}

Pergaulan bebas bisa dimaknai sebagai pergaulan remaja dengan lawan jenis tanpa batas atau tanpa ikatan aturan.

Pergaulan di kalangan remaja terutama di usia sekolah saat ini sangat mengkhawatirkan, oleh karena itu perlu mendapatkan perhatian dan pengawasan dari berbagai pihak terutama kedua orang tua. Pengawasan dan bimbingan perlu diberikan kepada anak supaya anak tidak terjerumus kedalam pergaulan bebas yang berdampak pada perilaku seks bebas remaja.

Pergaulan bebas bisa dilihat dari cara berpacaran remaja. Saat ini, gaya pacaran remaja sudah banyak berubah dan lebih berani. Banyak pasangan remaja yang menunjukkan kemesraan di tempat-tempat umum. Selain itu, di akun pribadi media sosial mereka banyak ditemukan foto-foto yang menunjukkan kedekatan mereka seperti sepasang suami-istri.

Remaja pada umumnya memiliki pemikiran yang cenderung labil dan keinginan untuk mencoba berbagai hal dalam kehidupan sehari-hari. Remaja memasuki usia subur dan produktif, artinya secara fisiologis telah mencapai kematangan organ-organ reproduksi, baik remaja laki-laki maupun remaja wanita. Kematangan organ reproduksi tersebut, mendorong untuk melakukan hubungan sosial baik dengan sesama jenis maupun dengan lawan jenis.

Keadaan remaja yang masih labil dan ingin mencoba melakukan banyak hal menjerumuskan remaja ke dalam pergaulan bebas. Pada pandangan ini seringkali remaja berpandangan bahwa masa pacaran merupakan masa dimana seseorang boleh mencintai maupun dicintai oleh kekasihnya, bentuk ungkapan rasa cinta atau kasih sayang dapat dinyatakan dengan berbagai cara, misalnya: pemberian hadiah bunga, berpelukan, berciuman, dan bahkan melakukan hubungan seksual. Hal ini senada dengan pendapat Hirmaningsih (1997) yang mengungkapkan bahwa adanya dorongan seksual dan rasa cinta membuat remaja ingin selalu dekat dan mengadakan kontak fisik dengan pacar.

\section{Perkembangan Teknologi Informasi dan Komunikasi}

Salah satu alat komunikasi yang banyak digunakan saat ini adalah internet, smartphone, 
facebook, whatsapp, twitter dan lain-lain. Saat ini, khususnya di Kecamatan Ponrang Selatan, banyak remaja yang memiliki smartphone. Penggunaan smartphone yang tidak dikontrol dengan baik, membuat alat canggih ini sering disalahgunakan oleh remaja untuk hal-hal yang negatif seperti menyimpan foto-foto ataupun video porno dan juga digunakan sebagai alat yang memperlancar komunikasi dengan lawan jenis untuk hal-hal yang kurang bermanfaat seperti melakukan fitur video call dengan menggunakan pakaian yang minim sehingga menimbulkan dorongan seks pada remaja.

\section{Tersedianya Tempat Wisata}

Tempat wisata adalah tempat yang banyak dikunjungi oleh semua kalangan, termasuk remaja. Pantai Salolo yang terdapat di wilayah Kecamatan Ponrang Selatan merupakan salah satu tempat yang dimanfaatkan pasangan remaja untuk melakukan tindakan asusila. Kondisi Pantai Salolo yang sepi karena belum memiliki fasilitas wisata yang baik serta ditumbuhi banyak pohon bakau di sepanjang garis pantainya dapat menghalangi pandangan orang terhadap aktifitas yang dilakukan di pantai itu, sehingga memberikan kesempatan kepada remaja untuk bebas melakukan hubungan seks karena merasa tidak dilihat oleh siapapun.

\section{Religiusitas}

Dalam faktor religiuitas, orang yang taat beragama dalam keadaan apapun selalu dapat menempatkan dan mengendalikan diri agar tidak berbuat hal-hal yang bertentangan dengan ajaran agama. Dalam hatinya selalu ingat Tuhan, sebab mata Tuhan selalu mengawasi setiap perbuatan manusia. Dalam hal ini, artinya pendidikan agama pada remaja di Kecamatan Ponrang Selatan kurang, sehingga banyak remaja yang tidak dapat mengendalikan dirinya dan mudah terjerumus melakukan hal-hal yang bertentangan dengan ajaran agama. Hal ini senada dengan pendapat Dariyo, (2004) yang mengatakan bahwa remaja yang tidak mampu mengendalikan diri karena religius rendah akan terlibat dalam kehidupan seksual, misalnya seks bebas atau seks di luar pernikahan.

\section{B. Dampak Putus Sekolah Kasus Hamil Pranikah \\ 1. Dampak Pendidikan}

Pada konsekuensi terhadap pendidikan, remaja yang hamil dan yang telah menghamili biasanya akan dikeluarkan dari sekolah oleh pihak sekolah (DO). Hal ini dilakukan karena pihak lembaga pendidikan tidak mau kalau nama baik sekolahnya tercemar. Begitu juga dengan remaja di Kecamatan Ponrang Selatan yang hamil pranikah, mereka mau tidak mau harus putus sekolah atau drop-out dari sekolah.

$\mathrm{Hal}$ ini senada dengan pendapat Faturochman (dalam Anastasia, 2001) yang mengatakan bahwa bahwa di negara lain juga di Indonesia, remaja yang berhubungan seks di luar nikah dan kemudian mengalami kehamilan di luar nikah tidak diperbolehkan untuk melanjutkan sekolah. siswa yang terbukti hamil sebelum menikah tidak dapat lagi melanjutkan pendidikannya di sekolah karena adanya aturan yang mengatur hal tersebut.

\section{Dampak Psikologis}

Pada konsekuensi psikologis orang tua yang anaknya hamil akan menanggung rasa malu. Maka untuk menyelesaikan masalah ini, jalan terbaik adalah segera menikahkan anaknya yang hamil dengan laki-laki yang menghamilinya. Hal ini juga sama dengan yang dialami orang tua remaja hamil pranikah di Kecamatan Ponrang Selatan, mau tidak mau mereka harus segera menikahkan anak mereka karena ini jalan terbaik. Konsekuensi ini sangat terasa bagi pelaku dan keluarga saat teman dan masyarakat baru saja mengetahui kasus yang sedang terjadi. Adanya perasaan malu membuat ruang gerak pelaku dan keluarganya terbatas. Akibatnya, proses bermasyarakat tidak berjalan seperti biasanya.

Pelaku merasa malu untuk bertemu dengan teman sekolahnya. Hal yang sama terjadi pada orang tua. Orang tua remaja yang mengalami putus sekolah akibat hamil pranikah sangat malu kepada masyarakat di lingkungannya karena merasa telah gagal mendidik seorang anak dan kejadian seperti ini biasanya menjadi bahan perbincangan dalam masyarakat. Beberapa aktifitas di luar rumah apalagi yang berhubungan langsung dengan masyarakat terganggu bahkan terhenti karena rasa malu untuk menampakkan diri di tengah-tengah masyarakat.

\section{Dampak Sosial}

Konsekuensi sosial atau sangsi sosial remaja yang mengalami kehamilan pranikah yaitu hubungan yang tidak harmonis dengan orang tua. beberapa remaja yang mengalami kehamilan pranikah juga menyebabkan hubungan dengan orang tuanya menjadi tidak harmonis. Hal itu dikarenakan kekecewaan dari orang tua yang telah membesarkan dan menyekolahkan anaknya dengan harapan agar bisa mendapatkan kesuksesan harus berakhir 
karena kehamilan tersebut. Hubungan yang tidak harmonis akibat kekecewaan dari orang tua sangat terasa sejak orang tua mengetahui bahwa anaknya sedang hamil sampai beberapa waktu hingga orang tua perlahan-lahan menerima anaknya kembali. Hal ini senada dengan penelitian yang dilakukan oleh Anita Indah Sari (2013), dimana salah satu dampak dari kehamilan pranikah remaja yaitu menyebabkan hubungan yang tidak harmonis dengan orang tua.

\section{Dampak Ekonomi}

Kasus hamil pranikah berdampak langsung pada pemenuhan kebutuhan ekonomis keluarga. Sebagai orang tua, tentu remaja harus bertanggung jawab untuk memberi pemenuhan kebutuhan ekonomi rumah tangga. Karena itu, mendorong remaja harus bekerja. Namun remaja yang putus sekolah mengalami kesulitan dalam mendapatkan kesempatan kerja karena tingkat pendidikannya terbatas atau karena sibuk mengurus anak. Terputusnya pendidikan ini secara signifikan mengurangi rentang kesempatan atau pilihan-pilihan di masa depan, terutama berkaitan dengan kesempatan dalam memeperoleh pekerjaan dan mencapai posisi ekonomi yang baik. Selain itu di usia remaja yang belum memiliki pengetahuan, keahlian, dan keterampilan yang cukup memadai, sehingga remaja yang bekerja hanya berpenghasilan rendah, tidak heran remaja masih bergantung kepada kedua orang tua untuk memenuhi kebutuhan ekonomi keluarga, seperti yang dialami sebagaian besar remaja hamil pranikah di Kecamatan Ponrang Selatan, yang rata-rata kebutuhan ekonomi masih dicukupi oleh orang tua. Hal ini sesuai dengan pendapat Kaplan (1997) bahwa dari segi sosial-ekonomi biasanya perempuan yang mengalami kehamilan di luar nikah masih tergolong dalam masa remaja sehingga dalam kehidupannya masih sangat tergantung dari orang tua atau pihak lain.

\section{B. Solusi Mengatasi Putus Sekolah Kasus Hamil Pranikah}

Kasus remaja putus sekolah yang terjadi di Kecamatan Ponrang Selatan sangat memprihatinkan, mengingat para remaja merupakan generasi penerus bangsa. Oleh karena itu masalah ini harus segera diatasi dengan mencari tahu bagaimana solusi untuk mencegah putus sekolah kasus hamil pranikah ini. Berdasarkan observasi dan hasi wawancara dengan beberapa informan pencegahan remaja putus sekolah kasus hamil pranikah ini dapat dilakukan melalui keluarga, sekolah dan pendidikan agama (religiusitas).

\section{Keluarga}

Keluarga merupakan tempat sosialisasi pertama bagi anak dan merupakan pendidik pertama bagi seorang anak. Perhatian serta pengawasan orang tua terhadap anak dapat mengurangi terjadinya fenomena hamil di luar nikah. Selain itu komunikasi yang baik antara orang tua dengan anak menjadikan anak lebih terbuka kepada orang tua. Peran serta keluarga memberikan arti yang besar bagi anak untuk tumbuh dan berkembang d ilingkungannya. Orang tua harus aktif dalam mengontrol pergaulan anak, seperti menanyakan dengan siapa dan ke mana ia bergaul. Membangun komunikasi yang baik dengan anak juga adalah cara yang seharusnya digunakan orang tua untuk mengetahui kehidupan anak di luar sana agar terhindar dari seks bebas yang mengakibatkan terjadinya kehamilan pranikah. Seperti pendapat dari Dagun (Yuwanto, 2002) yang mengatakan bahwa peran orangtua dalam hal komunikasi akan membantu remaja dalam memahami dan mengerti perilaku tertentu terutama perilaku seksualnya sehingga dapat menghindari perilaku seks pranikah. Komunikasi dalam keluarga mempunyai peranan penting bagi remaja untuk menyelesaikan masalah yang dihadapinya.

\section{Sekolah}

Sekolah merupakan lembaga pendidikan formal yang sistematis melaksanakan program bimbingan, dan latihan dalam rangka membantu siswa agar mampu mengembangkan potensinya baik yang menyangkut aspek moral, spiritual, intelektual, emosional maupun sosial (Yusuf, 2001:54). Sekolah selain sebagai tempat mengajarkan ilmu pengetahuan juga merupakan tempat untuk membentuk karakter remaja yang bersusila. Lewat lembaga pendidikan ini, remaja diharapkan memiliki akhlak dan perilaku positif melalui pembelajaran yang dilakukan oleh guru dan semua komponen yang ada di dalamnya.

Selain itu, implementasi nyata yang bersentuhan langsung dalam pencegahan kasus remaja putus sekolah akibat hamil pranikah ialah melalui pendidikan seks di sekolah. Pendidikan seks merupakan salah satu cara untuk mengurangi atau mencegah penyalahgunaan seks, khususnya untuk mencegah dampak-dampak negatif yang tidak diharapkan seperti kehamilan di luar nikah, penyakit menular (PSM), depresi dan perasaan berdosa (Sarlito, $2004:$ 182). 
Materi pendidikan seks baik dari guru maupun orang-orang yang berkompeten pada bidang tersebut setidaknya akan mengubah pola pikir remaja dalam memandang seks. Remaja akan berhati-hati melakukan seks bebas setelah mendapatkan penjelasan rinci mengenai bahaya dan dampak yang timbul akibat seks di luar pernikahan. Penyampaiannya perlu dibuat secara menarik agar siswa secara sadar diri dapat mengambil sikap terhadap hubungan seks pranikah secara bijaksana dengan sendirinya tanpa paksaan dari siapapun, karena kesadaran diri dari remaja itu sendiri merupakan cara yang paling penting dalam mencegah hubungan seks pranikah.

\section{Agama}

Shaleh, (2000) mengungkapkan bahwa pendidikan agama merupakan hal yang penting untuk mencapai hasil yang diharapkan dari pendidikan agama terutama pada jenjang sekolah di masa remaja yakni :siswa dapat menumbuh kembangkan keimanan dalam dirinya dan mampu mengembangkan akhlak budi pekerti yang baik serta mengenal nilai moral agama dalam hubungan manusia dengan alam dan manusia dengan Tuhannya.

Di era modernisasi, nilai-nilai religiutas tampak jelas telah tergerus. Kepentingan agama berada di bawah kepentingan-kepentingan lain yang bersifat duniawi. Fenomena buruk tersebut memasuki kehidupan semua lapisan masyarakat dunia saat ini. Penyimpangan yang dilakukan remaja yaitu hubungan seks yang berujung pada kasus putus sekolah adalah bentuk nyata bagaimana pengamalan agama tidak lagi diterapkan dalam kehidupan.

Menjadikan agama sebagai petunjuk yang mengatur sistem kehidupan adalah satu cara yang efisien untuk mencegah penyimpangan-penyimpangan di kalangan remaja. Penanaman nilai-nilai keagamaan sangat penting untuk menguatkan iman sebagai kontrol bagi remaja dalam berperilaku. Pendidikan agama sejak dini sangat penting diberikan kepada anak melalui orang tua. Pengenalan agama dapat dimulai sejak anak masih dalam kandungan berdasarkan cara-cara tertentu dalam setiap agama. Orang tua harus mendidik anak melalui kebiasaan-kebiasaan yang berlandaskan nilai-nilai keagamaan.

\section{SIMPULAN DAN SARAN}

Berdasarkan hasil penelitian dan pembahasan di atas. Dapat disimpulkan bahwa:
1. Dari hasil penelitian ditemukan bahwa Faktor yang menyebabkan remaja putus sekolah kasus hamil pranikah yaitu: faktor keluarga, yaitu kurangnya pengawasan dari orang tua, pengaruh pergaulan bebas (pacaran) yang melanggar nilai, norma dan agama dengan lawan jenis tanpa ikatan pernikahan, pengaruh perkembangan teknologi informasi dan komunikasi, tersedianya tempat wisata dan kurangnya pendidikan agama yang dimiliki remaja.

2. Dampak yang ditimbulkan bagi pelaku maupun keluarga antara lain yaitu: dampak pendidikan, dampak sosial, dampak psikologis dan dampak ekonomi.

3. Solusi mengatasi remaja putus sekolah kasus hamil pranikah yaitu dapat dilakukan melalui keluarga, sekolah dan pendidikan agama. Melalui keluarga yaitu dengan Memberikan perhatian lebih kepada anak remajanya, seperti mengawasi dan mengontrol pergaulan anak remajanya serta membangun komunikasi yang baik dengan anak. Selanjutnya melalui sekolah dapat dilakukan dengan memberikan pendidikan seks bagi siswa, serta melalui pendidikan agama, yaitu dengan menanamkan pendidikan agama kepada anak dalam kehidupan sehari-hari melalui keluarga, serta di sekolah yaitu dengan diprogramkan kegiatan keagamaan yang melibatkan siswa di dalamnya.

Sehubungan dengan kesimpulan di atas, maka melalui tulisan ini disarankan kepada:

1. Bagi remaja, menghindari perilaku berpacaran bebas, lebih berhati-hati dalam bergaul dengan lawan jenis, lebih memperbanyak ibadah supaya bisa menahan diri agar tidak terjerumus ke halhal yang dilarang agama, lebih banyak belajar dan memahami tentang pendidikan Islam, nilai-nilai pendidikan, terutama dalam pergaulan.

2. Bagi Orang Tua , Orang tua harus lebih mengontrol dan mengawasi pergaulan anak terkait dengan pergaulannya agar tidak mengalami hamil di luar nikah dan orang tua diharapkan menanamkan pendidikan agama kepada anak dalam kehidupan sehari-hari serta memberikan pendidikan seks sejak dini agar anak tidak terjerumus dalam pergaulan bebas.

3. Lembaga sekolah agar melakukan pembinaan dan pendidikan tentang bahaya seks bebas yang berakibat pada hamil pranikah, perlunya penanaman nilai-nilai 
moral dan etika, budaya malu bagi para remaja agar tidak terjerumus pada tindakan yang menyimpang dan melanggar nilai dan norma yang berlaku, serta menjalin kerja sama dengan orang tua siswa dalam hal pengawasan remaja.

\section{DAFTAR RUJUKAN}

Al-Husaini, Aiman, 2008. Tahun Pertama Pernikahan. Bandung: Universitas Pendidikan Bandung

Anastasia, H. 2001. Dampak Psikologis Perempuan Hamil Di Luar Nikah. Semarang : Fakultas Psikologi Universitas Katolik Soegijapranata

Bagong, Suyanto. 2010. Metode Penelitian Sosial. Jakarta : Prenada Media Group

Bagong, Suyanto. Sutinah. 2005. Metode Penelitian Sosial Sebagai Alternatif Pendekatan. Yogyakarta : Pustaka

Dagun, M. S. 2002. Psikologi Keluarga. Jakarta : Rineka Cipta

Dariyo, Agus. 2004. Psikologi Perkembangan Remaja. Bogor Selatan: Graha Indonesia

Hurlock, E.B. 1993. Perkembangan Anak. Jilid 2. Penerjemah : Meitasari Tjadrasa. Edisi ke-6. Jakarta : Erlangga

Kaplan, H.I ; Sadock, B.J ; Grebb, J.A. 1997. Sinopsis Psikiatri (edisi Ketujuh). Jakarta : Binarupa Aksara

Khisbiyah, Yayah, Desti Murdijana, dan Wijayanto. 1996. Kehamilan Tak Dikehendaki di Kalangan Remaja. Yogyakarta : PKBI dan Ford Foundation

Martono HS dan Saidiharjo, 2002. Geografi dan Kependudukan. Solo. Tiga Serangkai.

Monks, F.J ; Knoers, A.M.p \& Hadinoto S. R. 2001. Psikologi Perkembangan : Pengantar dalam Berbagai Bagiannya. Yogyakarta: Gajah Mada University Press
Mudyahardjo, Redja. 2001. Pengantar Pendidikan Sebuah Studi Awal tentang Dasar-dasar Pendidikan pada Umumnya dan Pendidikan di Indonesia. Jakarta : PT Raja Grafindo Persada

Mussen, P.H. 1994. Perkembangan dan Kepribadian Anak ( Terjemahan Budijanto, F.X., dkk) Jakarta : Arehan

Rahman, A \& Hirmaningsih. 1997. Pacaran Sehat. Panduan Ceramah. Yogyakarta : Sahabat Remaja

Ritzer, Goerge. 1985. Sosiologi Ilmu Berparadigma Ganda. Jakarta : Rajawali Pers

_Sarwono, Sarlito Wirawan.2001. Psikologi Remaja. Jakarta : Raja Grafindo Persada. 2004. Psikologi

Remaja. Jakarta : CV Rajawali

Soetriono. 2007. Filsafat Ilmu dan Metodologi Penelitain. Yogyakarta: CV. Andi Offset

Sudarsono. 2004. Kenakalan Remaja. Jakarta: PT Rineka Cipta

Sugiyono. 2008. Metode Pendidikan Pendekatan Kuantitatif, Kualitatif, dan $R \& D$. Bandung : Alfabeta . 2014. Metode Penelitian Pendidikan Pendekatan Kuantitaif, Kualitatif, dan $R \& D$. Bandung : Alfabeta

2016. Metode Penelitian Kuantitatif, Kualitatif, dan $R \& D$. Bandung : PT Alfabet

Suprayogo, Imam dan Tobroni. 2003. Metode Penelitian Sosial Agama. Bandung : Rosda

Yusuf, Syamsu. 2000. Belajar dan Faktor-faktor yang Mempengaruhinya. Rineka Cipta. Jakarta

\section{Sumber Lain}

Sari, Anita Indah, 2013. Fenomena Hamil di Luar Nikah Pada Masyarakat Desa Wonokromo Kecamatan Alian Kabupaten 
Phinisi Integration Review. Vol 2(2) Agustus 2019

Kebumen. Jurnal Pendidikan, Vol. 2, No.

8 